\title{
THE BREEDING PROGRAM OF SEEDLESS GRAPES, THE EXISTING PROBLEMS IN REPUBLIC AND A PROSPECTS OF INTRODUCING THE GEN TECHNOLOGIES
}

\author{
Sadulla Abdullaevich Abdullaev \\ Fellow Researcher, Laboratory of Transgenomics and Cell Culture, \\ Center of Genomics and Bioinformatics, Academy of Sciences of the Republic of Uzbekistan, Tashkent, \\ Uzbekistan
}

Mukhammadlatif Marufjon o'gli Nazirov

Intern Researcher, Laboratory of Bioinformatics, Center of Genomics and Bioinformatics, Academy of Sciences of the Republic of Uzbekistan, Tashkent, Uzbekistan

\begin{abstract}
Abduvokhid Abdullaevich Bolqiev
Intern Researcher, Laboratory of Transgenomics and Cell Culture, Center of Genomics and Bioinformatics, Academy of Sciences of the Republic of Uzbekistan, Tashkent, Uzbekistan

Shakhnoza Akhatullaevna Sultonova

Intern Researcher, Laboratory of Transgenomics and Cell Culture, Center of Genomics and Bioinformatics, Academy of Sciences of the Republic of Uzbekistan, Tashkent, Uzbekistan
\end{abstract}

\section{Khurshida Abdullaevna Ubaydullaeva}

Doctor of Biological Science, Head of the Laboratory of Transgenomics and Cell Culture, Center of Genomics and Bioinformatics, Academy of Sciences of the Republic of Uzbekistan, Tashkent, Uzbekistan

\section{Zabardast Tajiboevich Buriev}

Doctor of Biological Science, Head of the Scientific Research Department, Center of Genomics and Bioinformatics, Academy of Sciences of the Republic of Uzbekistan, Tashkent, Uzbekistan

\author{
Ibrokhim Yulchievich Abdurakhmonov \\ Academician, Director of the Center of Genomics and Bioinformatics, Academy of Sciences of the \\ Republic of Uzbekistan, Tashkent, Uzbekistan
}

Article DOI: https://doi.org/10.36713/epra3957

\begin{abstract}
This article discusses problems in the breeding programs of the seedless grapes, the way of introducing of the biotechnology and gene technology skills to resolve its issues, and the advantages of molecular markers to select seedlessness among the hybrid progeny of grapes. Uzbekistan is famous for its seedless grapes, but on the other hand, the grape breeding is oriented on the conventional breeding method. In other words, seedless grapes have a recessive character, a male form is using only as a pollinator, and all these factors limit to create new seedless varieties and forms. Nowadays the word grape breeders, especially seedless grape breeders use advantages of the biotechnology and gene technology skills to resolve above listed

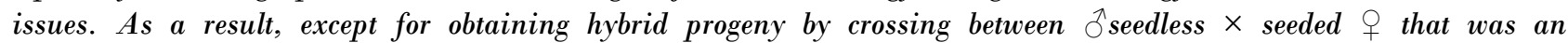
unchangeable algorithm of the cross combination in the traditional grape breeding. But today, researchers argued that crossing between $\widehat{\jmath}$ seedless $\times$ seedless $\bigcirc$ is also possible to obtain a hybrid progeny through "embryo rescue technique". Thus introducing this novel breeding program directly to grape breeding of Uzbekistan leads to an increase the diversity of the new seedless grape varieties and also for increasing the export potential of the grape industry.

KEYWORDS: Seedless grape varieties, variety, cross combination, embryo culture, molecular markers, DNA.
\end{abstract}




\section{SJIF Impact Factor: 6.260| ISI I.F.Value:1.241| Journal DOI: 10.36713/epra2016 ISSN: 2455-7838(Online) EPRA International Journal of Research and Development (IJRD)} Volume: 5 | Issue: 1 | January 2020

- Peer Reviewed Journal

\section{INTRODUCTION}

The grape industry has a leading position with its highly profitable in the agriculture sector. According to FAO- OIV FOCUS (2016) grape with its 68.9 million tons of products was mostly consumed after banana, orange and apple fruits. Nowadays, the grape plantations area reach nearly 7.5 million hectares (banana plantation $5.6 \mathrm{mln}$ hectare, FAOstat, 2017) and with a yearly production of grapes accounted for $90 \mathrm{mln}$ ton ${ }^{1}$.

Modern world market has high demand on the grape fruits but in the marketing system excises some requirements. For instance, fruit color and its uniformity within the cluster (Clydesdale, 1993), berry size and color significant, but also are the condition of the cluster rachis, which should be green and firm (Winkler, 1974) and the cluster size and shape (Cliff, 1996) which is usually modified earlier in the season but can be adjusted at harvest, too. Fruit texture is also important, with a crisp flesh generally being desired over those that are softer (Cliff et al., 1996; Sato and Yamada, 2003). Requirement on the world market is strongest for table grapes and seedless grapes.

Requirement on the world market is strongest for table grapes and seedless grapes. but seedlessness of grapes one of the privilege character of grapes to take place on the world market (California table grape Commission, 1995).

Uzbekistan is known across the world for its seedless grape varieties and its history goes back to the distant past. For instance, the "Oq Dum" seedless variety of grape that maintained from the Amir Temur (1336-1405 y) dynasty and still cultivated in the Samarqand region. This fact, shows that grape cultivation was a traditional heritage for the Uzbek nation. Especially, all famous Uzbek seedless grapes come result of folk breeding and its history has to background distant past.

So far, Uzbekistan's grape breeding has been organizing on the base of the conventionally breeding method and has been obtained some best seedless varieties like "Oq Kishmish" "Qora Kishmish", "Kishmish Samarqand", "Kishmish Irtyshar", "Kishmish Sogdiana", "Kishmish Sumbula", "Kishmish Duoba".

Despite this result, traditionally breeding program has disadvantages, recessive inheritance, using seedless grapes only as a "male" parent those all limit to create new varieties and forms.

But introducing a modern grape breeding program in this sector can be resolved existence limitation. Thus in seedless grape breeding "embryo rescue technique" allows to find a solution.
Nowadays many grape breeders and researchers for increasing diversity of grapes with seedless varieties in their country are using the "embryo rescue technique". For this purpose, DNA markers play an important role in accelerating the breeding process.

\section{BREEDING SEEDLESS GRAPE VARIETIES}

Grape breeding is also based using of genetic biodiversity as the same other agriculture crop breeding. The research process is expanding across the world to study of Vitis family, its genera and species their existing and widely cultivated varieties. The genetic and molecular study of the diversity of Vitis family, along with the preservation of its genetic integrity, serves as the basis for the selection of new varieties and forms with valuable economic features. Because, the research process on the molecular biology level of the Vitis family serve to conserve integrity genetic diversity, and to select new valuable variety and form (Ilnitskaya, Makarkina, 2016).

In the traditional breeding technique of grapes is a difficult to obtain hybrid progeny. It is known that seedless grape fruits develop either through parthenocarpy or stenospermocarpy. Parthenocarpy grapes develop fruits without pollination, but in stenospermocarpy grapes fertilization occurs subsequent embryo development soon stops and aborted. It is one of the main and unresolved barer for the conventional breeding programs and secondly all seedless stenospermocarpy grapes are sterile and recessive (Temurov, 2002).

Early hybridization of grape varieties was mainly carried out between species of Vitis vinifera and $V$. rotundifolia. It has been performed by some breeders as Goldy (1902), Jelenkovic and Olmo (1968), Olmo (1971), Patel and Olmo (1986) (Clingeleffer, 1998).

In 1933, the breeding program of seedless grapes has been also organized in Uzbekistan by researchers at the Institute of Plant Industry and at the ScientificResearch Institute of Horticulture, Viticulture, and Winemaking named after Academician M. Mirzaev (Javakyants, Gorbach, 2001).

Until the 40th of the last century, this research direction of grape breeding was the main target (Negrul, 1952). Since the 1950s due to the recessive character of seedless grapes have been isolated as separate scientific research (Mirzaev, Rizaev, 2010).

\section{PROBLEMS OF BREEDING}

Until now, selection of sorts of seedless grapes in the Republic is based on traditional methods, which are the following combinations for obtaining new generation:

\footnotetext{
${ }^{1}$ FAOstat, 2017. http://www.fao.org/faostat/en/\#data/QC 


\section{male (o') seedless}

and this combination was considered to be an unchanging algorithm. On the other hand, some grape breeders as Negrul A.M. (1969), Javakyants Yu.M. (2001) Temurov (2002), M.M. Mirzaev, R.M. Rizaev (2010), Spiegel-Roy et al. (1985), Lahogue et al. (1998), Tangolar et al., (1999), Doligez et al., (2002), Mejia and Hinrichsen (2003), Adam Blondon et al. (2003), Fatahi et al. (2004), Fanizza et al. (2005), Cabezas et al. (2006), Constantini et al. (2008), Kim Myung Su, Jun Park, Dong Hun Lee, Youn Young Hur, Dong Jun Im (2019) claimed some disadvantages, there are:

- seedless grapes are nearly recessive, for instance, Sharma and Uppal (1977), Loomis, Weinberger (1979), claimed that recessives of seedlessness might be nearly 65-70\%, when David W. Ramming, Richard L. Emershad, Ronald Tarailo (2001) from $97,8 \%$ to $98,7 \%$;

- the pollen of seedless grapes are sterile;

- in the cultivation process of progeny generation after breeding, vigor ability of seeds completely decreased, in result possibilities of obtaining progeny generation is to be complex;

- a long breeding cycle (approx. 20-30 years).

On the one hand, those characters are genetic, and on the other hand, above-listed factors limited the spreading of seedless grape variety across the world widely. According to a report by the International Organisation of Vine and Wine (OIV), 15000 grape varieties listed and a mere 150 registered as seedless.

Nowadays, biotechnology achievement has been widely used to resolve these issues. Especially, achievement of embryology or embryo culture, is also known as embryo rescue, is one the earliest and successful forms of the breeding program for grapes. Embryo rescue was first documented in the 18th century when Charles Bonnet excised Phaseolus and Fagopyrum embryos and planted them in soil and the cross resulted in dwarf plants (Sharma et al., 1996). After this, from the beginning of this century when Hannig (1904) cultured embryos of Cruciferae excised from a few taxa such as Raphanus spp. and Chochlearia damica in a medium under aseptic conditions and succeeded in obtaining plants. The excising and culturing of cherry embryo in 1933 by Tukey, began a significant event in the embryo culturing of fruit crops. This event began widely using the embryo in many fruit crops, as apple (Dantas et al., 2006; Druart, 2000), banana (Bakry, 2008; Uma et al., 2011), citrus (Viloria et al., 2005; Xie et al., 2013, 2014), mango (Krishna and Singh, 2007), muskmelon (Ezura et al., 1994; Nuñez-Palenius et al., 2006), peach (Anderson et al., 2002; Pinto et al., 1994), persimmon ( $\mathrm{Hu}$ et al., 2013; Leng and Yamamura, 2006; Yamada and Tao, 2007), and watermelon (Taskın et al., 2013), etc. for various purposes such as seedless breeding, triploid breeding, and interspecific breeding breeding (Jun Li, Xianhang Wang, Xiping Wang, Yuejin Wang, 2014). Two scientists Emershad and Ramming utilized first application of ovulo embryo culture and in 1982 reported that "embryo rescue" technique was successfully utilized in grape breeding. Soon after, Cain et al. (1983), Gray et al. (1990), Brar et al. (1991) obtained normal embryos and seedling plants from abortive ovules of seedless grape (Bhaskarareddy, 2008). The "embryo rescue" technique affords an attractive alternative for by allowing the recovery of progeny from abortive ovules of two seedless grape variety crosses:

$\begin{gathered}\text { Thompson Seedless }\left(\sigma^{\prime}\right) \\ \text { Seedless varieti }\end{gathered} \times \begin{gathered}\text { Sultanina Seedless }(q) \\ \text { Seedless varieti }\end{gathered}$

According to Xianhang Wang ва Xiping Wang (2014), the success of the "embryo rescue" technique depends on some factors. For instance, the stage of maturity of the embryo and the composition of the growth medium plays a key role (Sharma et al., 1996). Moreover, observation specifically using grape have demosntrated that in this species the main factors influencing in ovulo embryo rescue are genotype (Cain et al., 1983; Gribaudo et al., 1993; Liu et al., 2003; Ponce et al., 2000; Ramming et al., 1990; Singh et al., 2011; Tian and Wang, 2008), the age of the ovule upon removal (Gray et al., 1990; Ji et al., 2013; Liu et al., 2003; Notsuka et al., 2001; Pommer et al. 1995; Singh et al., 2011; Spiegel-Roy et al., 1985; Yang et al., 2007) and the nature of the culture medium (Amaral et al., 2001; Cain et al., 1983; Gray et al., 1990; Hiramatsu et al., 2003; Nookaraju et al., 2007; Sun et al., 2011; Tang et al., 2009; Yamashita et al., 1995, 1998), as well as other variables (Aguero et al., 1996; Bharathy et al., 2003, 2005; Bouquet and Davis, 1989; Fernandez et al. 1991; Korpa's, Hradilı'k, 2009; Singh et al., 2011).

It is known that the diversity of seedless grapes are different from its morphology, but one of the important aspects is rudiment mass (Negrul, 1952; Khachatryan, Martirosyan and Egiazaryan, 1978) and classification of rudimentary was divided into 4 category:

$$
\begin{aligned}
& 1^{\text {st }} \text { category }-0-6 \mathrm{mg} . \\
& 2^{\text {nd }} \text { category }-6,1-10 \mathrm{mg} . \\
& 3^{\text {rd }} \text { category }-10,1-14 \mathrm{mg} . \\
& 4^{\text {th }} \text { category }-14,1 \mathrm{mg} \text { and more }
\end{aligned}
$$

For the breeding program and grape breeders 1 st and 2nd category are considered more suitable and valuable. (Negrul, 1996; Smirnov, Kostrikin, Maistrenko, Ozerova, 2002). In the selecting process of the male or female forms of seedless grapes, the rudimentary category should be under the main focus to overcome seedlessness.

Second advantages of embryo rescue is shortening the breeding cycle, when is used molecular markers, 


\section{SJIF Impact Factor: 6.260| ISI I.F.Value:1.241| Journal DOI: 10.36713/epra2016 \\ EPRA International Journal of Research and Development (IJRD)}

Volume: 5 | Issue: 1 | January 2020

- Peer Reviewed Journal

which allowing for the early identification of plants that will produce seedless berries are very useful.

The second advantage of embryo rescue is shortening the breeding cycle when it is used molecular markers, which allows for the early identification of plants among hybrid seedlings (Bourquin, Sonko, Otlen, Walton, 1993).

\section{PROSPECT OF MOLECULAR MARKERS FOR EARLY SELECTION OF HYBRID PROGENY}

E.T. Ilnitskaya and M.V. Makarkinalar (2016) noticed, that the grape genomes the 4th most observed plants after Arabidopsis, Oruza sativa, Populus (poplar), and its size is relatively not huge: approximately 477 million bp $(\mathrm{n}=19)$ in comparison with (Oryza sativa) rice genome - $430 \mathrm{Mb}(\mathrm{n}=12)$. In the sequencing process of the grape, the genome was identified approximately 2 million SNP sites, and about 1.7 million genes and their position have been confirmed by QTL mapping in the genome. There is interest in using grape breeding program the molecular markers for shortening the breeding cycle and prediction seedlessness among hybrid seedlings (Cipriani et al., 2008).

The existing of a large number of identified DNA markers (Table) with determined position in the genome of diverse types (SSR, SNP) it gives possibility to map genes, that determine agricultural trait (Hewstone, Valenzuela, Munoz, 2006).

There are four DNA markers constructed for early prediction of seedless traits of grapes and two of them are SCAR-markers: SCC8 (Lahogue et al., 1998) and SCF27 (Mejía, Hinrichsen, 2003), and last two pairs are a gene specific of microsatellite markers VMC7F2 (Cabezas et al., 2006), and VMC6F11 (Arroyo-García, Martínez-Zapater, 2004).

Table

The studied grape genes and DNA markers for identifying its chromosome locus

\begin{tabular}{|c|c|c|c|c|}
\hline Traits & Gene name & $\begin{array}{l}\text { Chromosome } \\
\text { locus }\end{array}$ & DNA markers & Literature \\
\hline \multicolumn{5}{|l|}{ Resistant: } \\
\hline $\begin{array}{l}\text { Agrobacterium sp. } \\
\text { (bacterial cancer) }\end{array}$ & Rcg1 & 15 & $\begin{array}{l}\text { UDV-015 } \\
9 M 3-3\end{array}$ & Kuczmog et al., 2012 \\
\hline $\begin{array}{l}\text { Daktulosphaira } \\
\text { vitifoliae, (filloxera) }\end{array}$ & Rdv1 & 13 & $\begin{array}{l}\text { Gf13_9 } \\
\text { VMC8e6 }\end{array}$ & Zhang et al., 2009 \\
\hline \multirow{3}{*}{$\begin{array}{l}\text { Plasmopara viticola } \\
\text { (Mildew) }\end{array}$} & Rpv1 & 12 & VVIb32 & Merdinoglu et al., 2003 \\
\hline & Rpv3 & 18 & $\begin{array}{l}\text { UDV-112 } \\
\text { UDV-305 } \\
\text { VMC7f2 }\end{array}$ & $\begin{array}{l}\text { Welter et al., } 2007 \\
\text { Bellin et al., } 2009\end{array}$ \\
\hline & Rpv4 & 4 & $\begin{array}{l}\text { VMC7h3 } \\
\text { VMCNg2e1 }\end{array}$ & Welter et al., 2007 \\
\hline Seedlessness & Sdi & 18 & $\begin{array}{l}\text { VMC16f11 } \\
\text { VMC17f2 } \\
\text { p3_VvAGL11 } \\
\text { SCC8 }\end{array}$ & $\begin{array}{l}\text { Arroyo-García, Martínez- } \\
\text { Zapater, } 2004 \\
\text { Cabezas et al., } 2006 \\
\text { Mejía et al., } 2011 \\
\text { Doligez et al }\end{array}$ \\
\hline $\begin{array}{l}\text { Xiphinema index } \\
\text { (Nematode) }\end{array}$ & Xir1 & 19 & $\begin{array}{l}\text { VMC5a10 } \\
\text { 1N2R3b } \\
\text { M4F3R }\end{array}$ & $\begin{array}{l}\text { Xu et al., } 2008 \\
\text { Hwang et al., } 2010\end{array}$ \\
\hline
\end{tabular}

N. Mejía (2011) and his colleagues observed that the D-lineage MADS-box family gene of VvAGL11 is a candidate gene for seedlessness and is preferentially expressed in early seed development. They suggested that the most suitable marker for breeding program of seedlessness is STS marker p3-VvAGL11, which relates to the regulatory area of VvAGL11 gene and it includes locus of (GAGA)n. The authors suggested that the reliability of markers for early prediction have to be studied in the wider Genetic resources. However, it indicates that grape breeders of Uzbekistan also should introduce and studied purity of molecular markers into grape genetic resources. Unfortunately, neither molecular markers and biotechnological concepts for breeding programs of seedlessness are not used in indigenous grape varieties of Uzbekistan.

\section{CONCLUSION}

In the global market, the quality berry of grapes is determined by the quantity of rudiments. Uzbekistan is famous for its seedless (Kishmish) grapes and it plays a 


\section{SJIF Impact Factor: 6.260| ISI I.F.Value:1.241| Journal DOI: 10.36713/epra2016 ISSN: 2455-7838(Online) EPRA International Journal of Research and Development (IJRD)}

Volume: 5 | Issue: 1 | January 2020

key role to introduce embryo rescue in technique in increasing the export potential of the grape industry. In comprising with traditional breeding which is used in Uzbekistan, grape embryo rescue is more efficient and economical. Because, this technique is simple in use and holds a vast potential in rescuing the desirable embryos which may otherwise degenerate. The technique requires simple facilities, usually available in plant tissue culture laboratories.

Even embryo rescue technique is a unique method, it is required studying the stages of embryo development, degradation times and the SDI gene region function in the Uzbek grape varieties.

\section{REFERENCES}

1. Agricultural Research Service United States Department of Agriculture: www.ars.usda.gov

2. Alleweldt G. (1992). The genetic resources of Vitis. Genetic and geographic of grape cultivars, their prime names and synonyms. G.Alleweldt, E. Dettweiler. - Siebeldingen. FRG. -590 p.

3. Annual Report-2018, National Institute of Horticultural and Herbal Science, South Korea, NIHHS. Hort., 11-1390804-000493-10. pp. 35-36.

4. Bates R.P. (1985). The emerging Florida wine industry. J. Am. Wine Soc. pp.45-53.

5. Bharathy P.V., Karibasappa G.S., Biradar A.B., Kulkarni D.D., Solanki A.U., Patil S.G., Agarwal D.C. (2003). Influence of prebloom sprays of benzyl adenine on in vitro recovery of hybrid embryos from crosses of 'Thompson seedless' and 8 seeded varieties of grapes (Vitis spp.). Vitis, 42(4), pp. 199 202.

6. Bouquet A., Danglo T.Y. (1996). Inheritance of seedlessness in grapevine (Vitis vinifera L.). Vitis, 35, pp.35-42.

7. Bourquin J.C., Sonko A., Otlen L., Walton B. (1993). Restriction fragment length polymorphism and molecular taxonomy in Vitis vinifera L. Theor. Appl. Genet., 87, pp.431-438.

8. Brinduse E., Ionescu M., Tomescu M. (2005). Vinifera genotype breeding for resistance to downy mildew by inter-specific hybridization using irradiated pollen. Roman. Agril. Res., 22, pp. 33-39.

9. Burger P., Gerber C.A., Gerber A., Ellis P.J.L., Hajdu E., Borbar E. (2003). Breeding seedless grapes in South Africa by means of embryos rescue. Acta. Hort., 603, pp. 565-569.

10. Buzin N.P. (1953). Grape in the foothills and mountains of Uzbekistan. Gosizdat, Tashkent.

11. Cahoon G. A., Anderson L.G., Passewitz G.R., Hahn D.E., Oden A.E., Gruber R. (1985). Fresh market grapes from ohio vineyards. Ohio. pp. 37-40.

12. Cain D.W., Emershad R.L., Tarailo R.E. (1983). Inovulo embryo culture and seedling development of seeded and seedless grapes (Vitis vinifera L.). Vitis, 22, pp. 9-14.

13. California table grape commission. (1995). The distribution and per capita consumption of California table grapes by major varieties in United states and Canada. California table grape commission. Fresno, California, USA. -19 p.
14. Cheng C., Xu X., Singer S.D., Jun Li, Zhang H., Gao M., Wang L., Song J., Wang X.. (2013). Effect of $G A 3$ treatment on seed development and seedrelated gene expression in grape. Miguel A Blazquez, Instituto de Biología Molecular y Celular de Plantas, Spain. pp. 3-6.

15. Cipriani G., Marrazzo M.T., Di Gaspero G., Pfeiffer A., Morgante M., Testolin R. (2008). A set of microsatellite markers with long core repeat optimized for grape (Vitis spp.) genotyping”. BMC Plant Biol. pp. 27-32.

16. Clingeleffer P.R. (1998). Breeding table grape and raisin varieties. In breeding and biotechnology for fruit trees: Proceedings Japan-Australia International Workshop. pp.26-39.

17. Dudkin N.A. (1979). Ampelography and selection of grapes. Odessa, Oshi..

18. Emershad R. L., Ramming D.W., Serpe M.D. (1989). In ovulo embryo development and plant formation from stenospermic genotypes of Vitis vinifera. Amer. J. Bet. 76, pp. 397-402.

19. Emershad R.L., D. W. Ramming (1984). In-ovulo embryo culture of Vitis vinifera L. cv. Thompson Seedless. Amer. J. Bet. 71, pp. 873-877.

20. FAO International Organisation of Vine and Wine Intergovermental Organization, "Table and Dired grapes", FAO-OIV FOCUS, 2016. -4 p.

21. Hewstone O. N., Valenzuela B. J., Munoz C., (2006). Cultivar effect in the development of stenospermocarpic grape embryos cultured in vitro. Agricultura Tecnic., 66(2), pp. 124-132.

22. Ilnitskaya E.T., Makarkina M.V. (2016). Application of DNA markers in molecular breeding and genetic studies of grapevine. Vavilovskii Zhurnal Genetiki $i$ Selektsii $=$ Vavilov Journal of Genetics and Breeding, 20(4), pp.528-536. DOI 10.18699/VJ16.163

23. Javakyants Yu.M., Gorbach V.I. (2001). Viticulture of Uzbekistan. Tashkent, 29 p.

24. Kostrikin L.A. Maistrenko, V.A. Ozerova. (1992). Seedless grape varieties in the Lower Don region. Vinograd $i$ vino Rossii.

25. Li J., Wang X., Wang X., Wang Y., (2014). Embryo rescue technique and its applications for seedless breeding in grape. $3 \mathrm{p}$.

26. Mejía N., Soto B., Guerrero M., Casanueva X., Houel C., de los Ángeles Miccono M., Ramos R, Le Cunff L., Boursiquot J.M., Hinrichsen P., AdamBlondon A.F. (2011). Molecular, genetic and transcriptional evidence for a role of VvAGL11 in stenospermocarpic seedlessness in grapevine. BMC Plant Biol. pp. 11-18.

27. Mirzaev M.M., R.M. Rizaev. (2010). Project Bioversity International / UNEP-GEF «In Situ/On farm conservation and use of agrobiodiversity (fruit crops and their wild relatives) in Central Asia. In: Recommendations for farmers on drying grapes. Tashkent, pp. 10-25.

28. Negrul A.M. (1969). The origin and selection of grapes on the genetic basis. In: N.I.Vavilov and Agricultural science (N.I.Vavilov I selskohozyaystvennaya nauka). Moscow, pp.323-339 
29. Negrul A.M. (1959). New data on the origin of Central Asian grape varieties. Izd. TSHA. №14.

30. Negrul. A.M. (1952). Viticulture. Selhozgiz. Moscow, pp. 75-78.

31. Olmo H.P. (1986). The potential role of (Vinifera $\times$ Rotundifolia) hybrids in grape variety improvement. Experientia, 42, pp. 921-926.

32. Serrano A., Espinoza C., Armijo G., InostrozaBlancheteau C., Poblete E., Meyer-Regueiro C., Arce A., Parada F., Santibáñez C., Arce-Johnson (2017). Omics approaches for understanding grapevine berry development: regulatory networks associated with endogenous processes and environmental responses. Global Approaches in Grapevine Berry Development, University of British Columbia, Canada

33. Smirnov K.V., Kostrikin I.A., Maistrenko L.A. (2002). Seedless varieties and hybrid forms of grapes. Novocherkassk, Zaporoje, 54 p.

34. Smirnov K.V. (1998). Viticultura. Moscow izd-vo MSHA

35. Smirnov. K.V., Perepelitsina E.P. (1965). On the effect of gibberellin on seedless grape varieties and their processed products. Fizilogiya rasteniya, $-T$. 12, 2, pp. 306-312.

36. Standard for table grapes (CODEX STAN 255) FAO. 2007. 9 p.

37. Statistical Report on World Vitiviniculture. 2019.-6 $p$.

38. Tantasawat, P. O., Poolsawat, W. Chaowiset. (2015). Grapevine breeding and genetics. School of Crop Production Technology, Suranaree University of Technology, Nakhon Ratchasima 30000, Thailand, pp. 3-6.

39. Temuriv Sh. (2002). Viticulture. «Uzbek National encyclopedia». Tashkent, 150-190.

40. Troshin L.P. (2002). Improving the assortment of vineyards in Russia. Nauchnie obespechenie APK Kubani. Krasnodar

41. Vavilov N.I. (1929). The role of Central Asia in the origin of cultivated plants (preliminary report on the results of the expedition to Central Asia in 1929). Vavilov N.I., 1960. 2, -42 p.

42. Vicelaru K.G., Condur M. (1991). Mechanical properties of table grapes. Sadovodstvo, vinogradarstvo I vinodelie Moldavii, №4. 